\title{
Embryo Development of Tree Frog Polypedates leucomystax at Campus of State University of Malang
}

\author{
Pearlindah $^{1}$, Emy Kusumawati $^{1}$, Dian Ratri Wulandari ${ }^{1}$, and Dwi Listyorini ${ }^{{ }^{*}}$ \\ ${ }^{1}$ Biology Department, Faculty of Mathematics and Natural sciences, State University of Malang , Malang, Indonesia
}

\begin{abstract}
Tree frogs live in natural places which are unpolluted. Regarding their role as an ecological indicator, the decrease of frogs population in a particular habitat indicates the danger of environment quality decrease. Moreover, this condition can harm the frogs themselves. All kinds of frogs breed in aqueous environment such as ponds, marshes, and farming fields. One of the tree frogs, Polypedates lencomystax, which belongs to Familia Rachophoridae, is widely spread in Indonesia. This frog has yellowish brown skin with black spots or six lines extending from head to the posterior tip of body. A breeding couple of the frog produces foam nests on the water or plants around water body, where they will nest their fertilized eggs. This species produces over a hundred embryos in one spawning season. These embryos require appropriate conditions to develop normally in the nature. Frog embryo development may becomes a reference to understand how the frog population survives. This study focused on $P$. lencomystax with regards to its decrease in number due to the drying up of the environment and a lot lost of trees in Campus of State University of Malang. The development of $P$. lencomystax embryos in the reproduction foam was observed until it reached a tadpole stage. The result showed that the embryos developed in the foam until they hatched then they move out of the foam into the water under which they would continue their development. Considering that water body is a critical requirement for the development of P. leucomystax embryos, it is our responsibility to make any efforts to conserve not only the trees but also any type of water bodies including ponds, marshes, and farming fields as well.
\end{abstract}

\section{Keywords: embryo development, Polypedates leucomystax, Tree frog conservation}

\section{INTRODUCTION}

The amphibian lives in damp wooded areas and some species can't be separated from the water throughout their lives [1,2]. Amphibians are one class of vertebrates which consists of three orders: Caudata (Urodela), Gymnophiona (Apoda), and Anura [3]. Among those, Anura (frog and toad) and Gymnophiona are found in Indonesia. Aquatic and arboreal frogs have smooth skin, relatively long hind legs to their body, and the extensive webbing between their toes. Terrestrial toad, on the other hand, has bumped skin with large poisonous supraorbital glands and generally have stubby legs.

Amphibians are one of the biota that receive less attention in Indonesia. This is partly because these animals are less familiar to the general public and among Indonesian researchers [4].

\section{*Corresponding address:}

Dwi Listyorini

Biology Department, Faculty of Math. and Natural sciences, State University of Malang, Malang, Indonesia

Email: listyorini.alj@bio.um.ac.id
There is a negative perception that the frogs are toxic or repulsive [5]. Frogs have two roles, as bio-indicator [6] and un-separated component of bioecosystem [7]. Frogs have thin permeable skin sensitive to poor water and air quality; as such, pollution might decrease their population. As a component of the ecosystem, frogs have a very important role. Frogs are part of the food chain and may act as a natural insecticide. Frogs have large appetites and help keeping insect pest populations under control. The loss of frogs from an ecosystem would create a missing link that likely could not be filled by any other species [7].

Rhacophoridae is a family of tree frogs previously known as the Hylidae. This family is widely spread all over the world [2]. It is commonly known as shrub frogs or more ambiguously as "moss frogs" or "bush frogs". Some Rhacophoridae are called "tree frogs". Among the most spectacular members of this family are the numerous "flying frogs" [8]. there are 10 families of Anura live in Indonesia; those 
are Bombinatoridae (Discoglossidae), Megophryidae (Pelobatidae), Bufonidae, Lymnodynastidae, Myobatrachidae, Microhylidae, Pelodryadidae, Ranidae, Rhacophoridae and Pipidae. Among Rhacophoridae, Nyctixalus (2 types), Philautus (17 species), Polypedates (5 types), Rhacophorus (20 species) and Theloderma (2 types) [2].

We observed Polypedates leucomystax, a member of Rhacophoridae found at State University of Malang. Polypedates leucomystax has a wide finger with flat tip, extensive webbing between toes but nothing in finger; the skin texture is smooth without nodule, bump, on foldaway, yellowish brown skin with black spots and six lines extending from head to the posterior tip of body [2]. The species within this family vary in size, from 1.5 centimeters ( 0.59 in) to 12 centimeters (4.7 in). Like any other arboreal frogs, they have toes discs, and those of the genus Chiromantis have two opposable fingers on each hand. This family also contains the Old World flying frogs, including Wallace's flying frog (Rhacophorus nigropalmatus). These frogs have extensive webbing between their hands and feet, allowing them to glide through the air [8]. Polypedates leucomystax also known as Four-lined Tree Frog [2] usually lives among the plants or around swamps. As a member of amphibian, this species need water body for reproduction [9].

This paper describes the development of Polypedates leucomystax embryo in regards to environmental condition. As arboreal frog, this species need mating trees. Mating pair, while in amplexus, is held onto a branch of a tree, and beat their legs to form foam. The eggs are laid in the foam, and covered with seminal fluid, before the foam hardens into a protective casing. The foam is laid above a water source, so the tadpoles fall into the water once they hatch. The tree frog embryos do not have any physical tools to defend themselves. Most of their prior development and out of the foam stage cause them to expose themselves to many threats from predators such as ants [8].

\section{MATERIALS AND METHODS}

Observation toward Polypedates leucomystax was done in several areas in the State University of Malang to find Polypedates leucomystax. The observation was conducted during May until June. Frog reproduction foam found in the observed area was taken to the laboratory for further observation. The observation focused on the development of the embryo until it reached tadpole stage and the environment need. Data were recorded using Casio Exilim 14.1 MP digital camera.

\section{RESULT AND DISCUSSION}

Polypedates leucomystax tree frog was found in the yard around girls dormitory and the reproduction foam with development embryo was found in a pool sized $1.5 \mathrm{~m} \times 0.5 \mathrm{~m} \times 0.5 \mathrm{~m}$ (Figure 1).

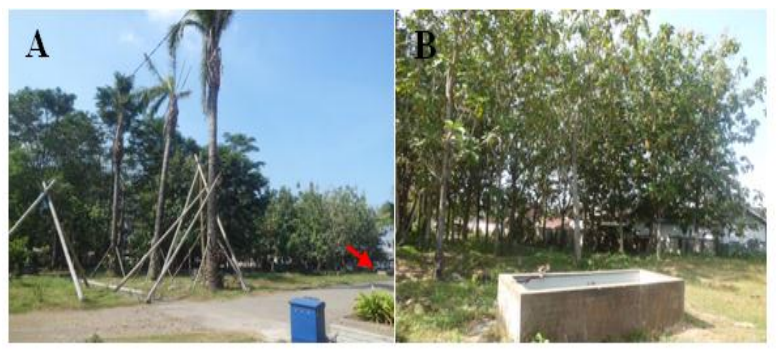

Figure 1. Female dormitory yard (A). The pond (B), red arrow in $\mathrm{A}$.

Polypedates leucomystax embryo was found in the reproductive foam attached on a twig which is immersed partly in the water (Figure 2). The size of the reproductive foam of Polypedates leucomystax was around $6 \mathrm{~cm}$ and the color was broken white. This foam is teared in some parts to expose the embryo. The size of an early embryo was around 1-2 $\mathrm{mm}$, the color is white and the shape is round (Figure 3, D-1).

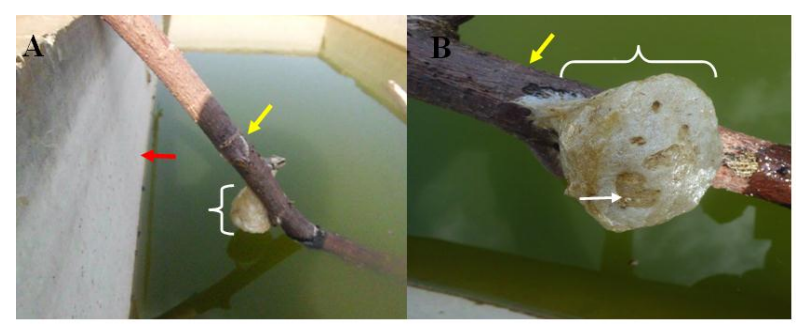

Figure 2. Polypedates leucomystax reproductive foam. Reproductive foam attached on a twig (A). Red arrow points the wall of the pond. White arrow points the developing embryo, bracked depicts the reproductive foam. Yellow arrow points the twig (B).

The embryo was developed in the foam until it reached a particular stage (a more careful study is required). The embryo then moved to escape from the foam. After successfully escaped from foam, the embryo fell into the water and continued their development. It was different from one described by Zweifel [8] in which the embryos fell into the water after reaching a tadpole stage. In our observation, the embryo 
was still in a ball shape, in the embryonic sac, when it escaped from the foam.

In the water, the embryo was actively moving for several seconsd then stayed quietly for one to two minutes and then moved again; through this movement the embryo-ball was growing bigger. We suggested that this was the embryogenesis stage, when an embryo raise its cell numbers and begins to form important organs (more careful study is required). After moving for several seconds, the embryo was quiet again for another one to two minutes. The next short-time movement seemed to be an effort to extend the embryonic body to be a larva with tail, but the embryo was still in thin-clear embryonic sac.

Following the quiet state, for a couple of minutes the embryo moved thoroughly, the body extended, then it hatched from the embryonic sac. In this stage, the heart had been formed and began to beat. This process took 2 days to complete (Figure 3D-2). The embryo continued growing by increasing its body size and tail length. It then became $24 \mathrm{~mm}$ in length within 35 days (Figure 3D-3 until D-35).

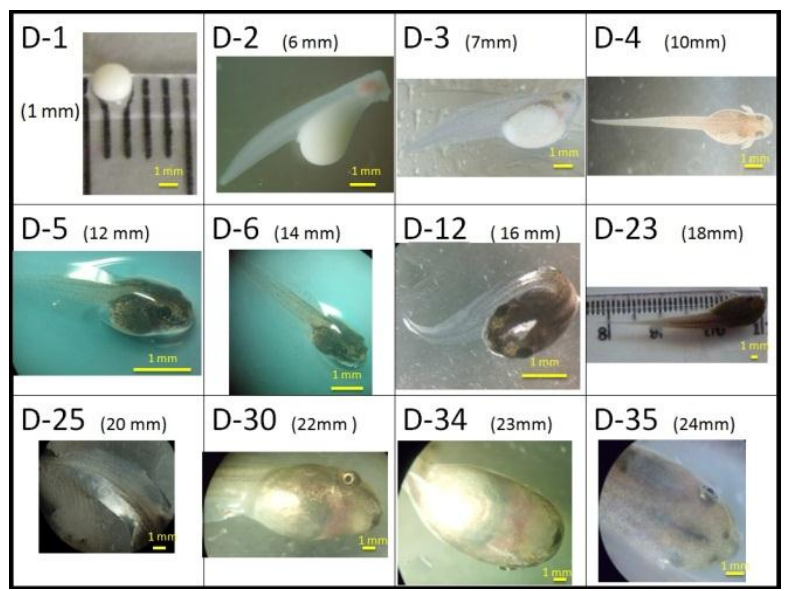

Figure 3. Developing of Polypedates leucomystax embryo. The first day of observation: the embryo sized 1 $\mathrm{mm}$ (D-1), the embryo escaped out of the foam on the second day (D-2), the heart beating was clearly visible on the third day (D-3), forming an external gills on the fourth day (D-4), black spots on the body began to appear, eyes and mouth was not yet fully formed on the fifth day (D-5), the length of the embryo extended from $12 \mathrm{~mm}$ to $14 \mathrm{~mm}$ on the sixth day (D-6), forming parts of the eye on the twelfth day (D12), the length of the embryo extended becoming $18 \mathrm{~mm}$ on the twenty third to the twenty fifth day (D-23-D-25), the mouth organ equipped with fully formed teeth on the thirtieth day (D-30), the length became $23 \mathrm{~mm}$ (D-34), nasal organ was formed on the thirty-fifth day (D-35).

The frog embryo development in nature is not always going well, sometimes the development of the embryo troubled and obstructed by some obstacles. The most important obstacles in the development of an embryo are predators and changes in environment. One important predator we observed was ants which ate the developing embryos. The ants from the soil around the pond came to the twig to get and to eat the embryo. The other obstacle is the changes in environment. The embryo needs water to develop until it reaches a mature stage. The changes in environment which reduce the water volume or shrink the water body will threaten the viability and development of tree frog embryo, and later will endanger its development to be a mature frog. In turn, it might endanger the survival of this species.

\section{CONCLUSION}

Polypedates leucomystax embryo development exclusively requires water body. The obstacles of the embryo development are predator and changes in environment. If the water body reduces or disappears, the viability and development of tree frog embryo will be threatened. If the environment continues to degrade, the survival of this species might be endangered.

\section{REFERENCES}

1. Mistar (2003) Panduan Lapangan Amfibi Kawasan Ekosistem Leuser, The Gibbon Foundation \& PILI-NGO Movement, Bogor.

2. Iskandar DT (1998) Amfibi Jawa dan Bali-Seri Panduan Lapangan, Puslitbang LIPI, Bogor.

3. John. Simon and Schuster's (1997), Guide to Reptiles and Amphibians of the World. Simon and Schuster, Inc., New York.

4. Iskandar DT \& WR Erdelen (2006) Conservation of amphibians and reptiles in Indonesia: issues and problems. Amphib. Reptile Conserv. 4(1):6093.

5. Kusrini MD, A Mardiastuti and A Fitri (2003) Promoting frog conservation through environmental education \& research experience: Pilot project in west java, indonesia. Dalam: M. D. Kusrini, A. Mardiastuti and T. Harvey (eds) Prosiding seminar hasil penelitian konservasi amfibi dan reptil di indonesia. Bogor, 8 Mei 2003. Bogor, Departemen Konservasi Sumberdaya Hutan.Institut Pertanian, 45-51.

6. Stebbins RC \& Cohen NW (1997) A Natural History of Amphibians. Princeton Univ. Pr., New Jersey.

7. Bishop D \& Fernandez-Juricic E (2005) Effect of direct human disturbance on the endemic Iberian 
frog Rana iberica at individual and population levels. Biological Conservation, 123, 1-9.

8. Zweifel Richard G (1998) Cogger, H.G. \& Zweifel, R.G. ed. Encyclopedia of Reptiles and Amphibians, Academic Press, San Diego.

9. Gilbert (2006) Developmental Biology Eighth Edition. Sinauer Associates, Inc.,Publishers Sunderland, Massachusetts USA. 